\title{
Food, Fiber and Flower Production and Use in Relation to Developing Strategies for Sustained Availability and Supply in Kathmandu Valley
}

\author{
Suroj Pokhrel \\ ${ }^{1}$ Ministry of Land Management, Agriculture and Cooperative, Singhadarbar, Kathmandu, Nepal. \\ ${ }^{2}$ Agriculture and Forestry University, Rampur, Chitwan, Nepal.
}

\begin{abstract}
How to cite this paper: Suroj Pokhrel. (2021) Food, Fiber and Flower Production and Use in Relation to Developing Strategies for Sustained Availability and Supply in Kathmandu Valley. International Journal of the Science of Food and Agriculture, 5(1), 97-107. DOI: $10.26855 /$ ijfsa.2021.03.014
\end{abstract}

Received: December 30, 2020

Accepted: January 28, 2021

Published: February 24, 2021

"Corresponding author: Suroj Pokhrel, Agriculture and Forestry University, Rampur, Chitwan, Nepal.

Email: surojpokhrel@yahoo.com

\begin{abstract}
Kathmandu valley is highly populated and most severe localized food insecure area, with limited land available for food, fiber and flower production in Nepal. Relevant literatures and available data were reviewed to find the trend of food availability and consumption in relation to developing strategies for sustained production and supply in the valley, in the year 2018. Study revealed that, the Import Dependency Ratio (IDR) of pulses, sugar, silk, jute, rubber, cotton, tea and wool were $100 \%$ in Kathmandu valley in 2018 . Where, the IDR of fish was $99.1 \%$, coffee $92.9 \%$, oils and ghee $90.8 \%$, spices $89.1 \%$, potato $87.7 \%$, cereals $87.4 \%$, milk $86.1 \%$, eggs $85.9 \%$, meat $85.2 \%$, vegetables $81.9 \%$, fruits $70.8 \%$, cut flowers $74.0 \%$ and honey $43.6 \%$. However, there was a scope to restore the self sufficiency on vegetables, potato, spices, and honey and minimizing the import of cereals, fruits, milk, meat and eggs through the adoption of improved urban agriculture in Kathmandu valley. Moreover, establishment of new commercial agriculture farms, expansion of cropping area/heard sizes and raising the productivity in/around valley and across the country, can restore the food/fiber/flower sufficiency. It needs to increase investment on agriculture, improve food habit and the consumption pattern, prioritize food production and distribution system, maintain at least $50 \%$ food deficit as buffer stocks, establish high tech agriculture infra-structures, mechanization, linking rural community to valley markets with strong planned, coordinated and participatory food and nutrition programs. It also needs to invest the rural agriculture by the valley/urban economy.
\end{abstract}

\section{Keywords}

Consumption, IDR, Nutrition, Sufficiency, Strategy

\section{Introduction}

There is rice culture and nutrition of local food is not known in Nepal. Diversification of local food products and subsidy support on local production are negligible [1]. Nepal ranks $82^{\text {th }}$ in Global food security index [2] and $72^{\text {nd }}$ in Global Hunger Index [3]. FAO classifies Nepal as severe localized food insecure country [1]. WFP [4] warns 3.9 million people in Nepal face food insecurity and $40 \%$ population undernourished. There lacks a well developed food marketing net work, collection and distribution system and infrastructures. Food productions are mainly in rural communities and are supplied to highly populated, urban areas. As long as the political systems do not support the rural farmers to grow foods they need for survival, the people will continue to resist [5]. Urbanization is one of the world's most transformative trends. 
Over half of the world's populations are living in cities, which are expected to be double by 2050. Unfortunately, city living often begets poor dietary choices with higher food waste. Own production can reduce the transportation cost and encourage having fresh and healthy foods, boost green spaces for healthier environments and reconnect cities with surrounding rural areas [6]. Majority of cities are unable to produce enough food to sustain their residents. However, some cities are exploring the idea that urban agriculture can create a more resilient food system. Yet, some argue that the global food system is too interconnected with the local food systems and that no system can exist without some level of vulnerability to external forces [7]. Urban agriculture can be highly productive in terms of yield per unit area; however productivity is limited by available land and high input requirements [8].

The markets of rural agriculture production are always the cities. Where, the city's populations are always feeding by the rural communities. Cities are always food deficit on their own production. The situation is true in case of capital city Kathmandu, Nepal too. Where, the overall food, fiber and flower situation seems low level of investment, poorly coordinated agricultural programs and is indicated as a localized severely food deficit area. Thus, linking the rural farmers to urban market especially to Kathmandu valley is vital that brings money from cities to village. The simplest way of ensuring wealth creation for the entire nation is to create free, fair and competitive market access to all levels of society, class, caste, and geographical locations [9].

This is why the research question was raised as "whether the food, fiber and flower production and use in Kathmandu valley is sufficient and how the ever growing valley population can be feed sustainably in future?" So, this study was designed with the overall objective of supporting on sustainable food supply in Kathmandu valley with the following specific objectives:

- to find the overall situation of food, fiber and flower production and use in Kathmandu valley.

- to make subsequent strategic recommendations for sustainable food, fiber and flower availability in Kathmandu valley.

\section{Methods}

Kathmandu valley was selected for the study because of high population density and severe localized food insecure area. Available reports from Government of Nepal, papers published from FAO and WHO, scientific papers, books and journal articles related to food and nutrition availability, hunger and malnutrition and population were collected and reviewed. Web pages were visited. The agriculture statistics like, crop area, livestock population, food productions, import and export were taken from secondary sources mainly from Ministry of Agriculture Development. The milling/dressing/processing returns of different commodities were calculated based on the following formula:

$$
\text { MRwt (\%) = Gwt (100)- Bpwt (\%)+Mls (\%) }
$$

where, $\mathrm{MRwt}=$ weight of product after milling/dressing/processing or the milling return

$\mathrm{Gwt}=$ gross weight/production after harvesting

Bpwt $=$ weight of by product/s

Mls $=$ milling $/$ dressing $/$ processing losses (wastage and moisture losses)

Example: Milling return of paddy [10]

where, Byproduct of rice (Bpwt) is husk (20\%), bran (5\%) and embryo (3\%) $=28 \%$

Moisture and wastage loss $(\mathrm{Mls})=2 \%$

Thus, MRwt $(\%)=100-28+2=70 \%$

Average milling return of cereals and pulses was considered 75\% (paddy 70, maize 92, wheat 99 and pulses $75 \%$ ) [10]. The table vegetables, spices and fruits were calculated by $65 \%-75 \%$ [11]. Where, it was $75 \%-85 \%$ on table potato [12]. Average dressing return of meat was estimated 75\% (mutton 72, Chicken 80 and Pork 75\%) [13]. The weight of processed tea/coffee estimated $75 \%$, oil extraction from oil seed $38 \%$ and sugar recovery $8 \%$ as per the standards. The recovery of milk, egg, wool and honey, calculated $100 \%$.

The food requirement ( $\mathrm{kg} / \mathrm{yr} /$ person) was calculated based on per capita food recommendations of Indian Council of Medical Research [14] and World Health Organization [15] that includes cereals (183 kg), pulses (26kg), green vegetables $(41 \mathrm{~kg})$ tuber $\&$, roots $(32 \mathrm{~kg})$, other vegetables $(32 \mathrm{~kg})$, fruits $(11 \mathrm{~kg})$, milk (55lit), meat \& fish $(11 \mathrm{~kg})$, eggs $(48 \mathrm{pc})$, sugar \& honey $(16 \mathrm{~kg})$ and fat \& oils $(16 \mathrm{~kg})$. The yearly food deficit (by consumption/recommendation) and needed area expansion or the needed rise in national productivity for the sustainable supply in Kathmandu valley was calculated. Food consumption was calculated based on the following formula:

Per capita food consumption $=$ Valley production $($ milled, $t)+$ import $($ milled,$t)-$ export $($ milled, $t)$ $(\mathrm{kg} / \mathrm{yr} /$ person) Valley population

The food self sufficiency ratio (SSR) and the import dependency ratio (IDR) were calculated based on the following formula: 
SSR $=$ Total consumption (milled, $t)-$ import $($ milled, $t) X 100$

$I D R=S S R-100$

$$
\text { Total consumption (milled, } t \text { ) }
$$

All the data derived from calculation were tabulated, analyzed and presented. Finally, the future strategy needed to have the sustained food, fibers and flowers supply in Kathmandu valley were recommended. This research did not receive any specific grant from funding agencies in the public, commercial, or not-for-profit sectors.

\section{Results}

\section{Food, fiber and flower production and balance in Kathmandu valley, 2017/018}

Consumable milled cereals production in the year 2017/018 in Kathmandu valley was only 98,894t but the actual consumption in the same year was 7,83,100t (Table 1). The consumption volume of cereals seemed slightly higher than the WHO and ICMR recommendation which could be 7,50,300t. Thus, there was a very big deficit of milled cereals on own production in Kathmandu valley. The deficit was 6,84,206t/year by consumption and 6,51,406t by ICMR [14] and WHO [15] recommendations. Other foods (pulses vegetables potato/tubers fruits spices sugar oilseed/ghee honey tea coffee meat fish cattle and buffalo milk and eggs) flowers rubber and fibers (wool cotton jute and silk) production and consumption/use in Kathmandu valley in the year 2017/018 were also in huge deficit (Table 1).

\section{Needed area/heard expansion or raising productivity for the sufficiency}

The huge deficit of food fiber and flower in Kathmandu valley can be met either by establishing new commercial production farms expansion of the area/heard size or raising the crop/livestock productivity in and around the valley and across the country (Table 2).

Table 1. Valley food balance (milled/processed/dressed), 2017/018

\begin{tabular}{|c|c|c|c|c|c|c|c|}
\hline SN & $\begin{array}{l}\text { Commodity } \\
\text { (processed) }\end{array}$ & $\begin{array}{c}\text { Per capita } \\
\text { need }[14,15]\end{array}$ & $\begin{array}{c}\text { Yearly } \\
\text { production } \\
{[16]}\end{array}$ & $\begin{array}{c}\text { Yearly } \\
\text { Consumption }\end{array}$ & $\begin{array}{c}\text { Need as per } \\
\text { Recommendation }\end{array}$ & $\begin{array}{c}\text { Deficit by } \\
\text { Consumption }\end{array}$ & $\begin{array}{c}\text { Deficit by } \\
\text { Recommendation }\end{array}$ \\
\hline 1 & Cereals & $183 \mathrm{~kg}$ & $98,894 \mathrm{t}$ & $7,83,100 \mathrm{t}$ & $7,50,300 \mathrm{t}$ & $6,84,206 \mathrm{t}$ & $6,51,406 \mathrm{t}$ \\
\hline 2 & Pulses & $26 \mathrm{~kg}$ & 0 & $47,150 \mathrm{t}$ & $1,06,600 \mathrm{t}$ & $47,150 \mathrm{t}$ & $1,06,600 \mathrm{t}$ \\
\hline 3 & Vegetables & $\begin{array}{c}73 \mathrm{~kg} \\
\text { (green } 41 \mathrm{~kg})\end{array}$ & $56,247 \mathrm{t}$ & $3,11,600 \mathrm{t}$ & $2,99,300 \mathrm{t}$ & $2,55,353 \mathrm{t}$ & $2,43,053 \mathrm{t}$ \\
\hline 4 & Potato/tubers & $32 \mathrm{~kg}$ & $50,500 t$ & $4,10,000 t$ & $1,31,200 t$ & $3,59,500 t$ & $80,700 t$ \\
\hline 5 & Fruits & $11 \mathrm{~kg}$ & $20,366 t$ & $69,700 \mathrm{t}$ & $45,100 \mathrm{t}$ & $49,334 \mathrm{t}$ & $24,734 \mathrm{t}$ \\
\hline 6 & Spices & - & $1,336 \mathrm{t}$ & $12,300 \mathrm{t}$ & $12,300 \mathrm{t}$ & $10,963.66 \mathrm{t}$ & $10,963.66 \mathrm{t}$ \\
\hline 7 & Sugar & $16 \mathrm{~kg}$ & 0 & $44,690 \mathrm{t}$ & $65,600 t$ & $44,690 \mathrm{t}$ & $65,600 t$ \\
\hline 8 & Oil/Ghee & $16 \mathrm{~kg}$ & $1,501 \mathrm{t}$ & $16,400 t$ & $65,600 \mathrm{t}$ & $14,899 \mathrm{t}$ & $64,099 \mathrm{t}$ \\
\hline 9 & Honey & NA & $500 \mathrm{t}$ & $886.9 \mathrm{t}$ & $2,050 \mathrm{t}$ & $386.9 \mathrm{t}$ & $1,550 \mathrm{t}$ \\
\hline 10 & Flowers & NA & Rs 104mil & Rs 200mil & Rs 400mil & Rs 96mil & Rs 296mil \\
\hline 11 & Tea & NA & 0 & $1,845 \mathrm{t}$ & $1,845 \mathrm{t}$ & $1,845 \mathrm{t}$ & $1,845 \mathrm{t}$ \\
\hline 12 & Coffee & NA & $5 \mathrm{t}$ & $70 \mathrm{t}$ & $70 \mathrm{t}$ & $65 \mathrm{t}$ & $65 \mathrm{t}$ \\
\hline 13 & Meat & $11 \mathrm{~kg}$ & $7,287 \mathrm{t}$ & $49,200 \mathrm{t}$ & $45,100 \mathrm{t}$ & $41,913 \mathrm{t}$ & $37,813 \mathrm{t}$ \\
\hline 14 & Fish & $11 \mathrm{~kg}$ & $250 \mathrm{t}$ & $28,700 t$ & $45,100 \mathrm{t}$ & $28,450 \mathrm{t}$ & $44,850 \mathrm{t}$ \\
\hline 15 & Milk & 55lit & $40,900 t$ & $2,95,200 \mathrm{t}$ & $2,25,500 \mathrm{t}$ & $2,54,300 \mathrm{t}$ & $1,84,600 \mathrm{t}$ \\
\hline 16 & $\operatorname{Eggs}(000 \mathrm{pc})$ & $048 \mathrm{pc}$ & $2,94,00 \mathrm{pc}$ & $20,91,00 \mathrm{pc}$ & $19,68,00 \mathrm{pc}$ & $17,97,00 \mathrm{pc}$ & $16,74,00 \mathrm{pc}$ \\
\hline 17 & Wool & NA & 0 & $412 t$ & $412 \mathrm{t}$ & $412 t$ & $412 t$ \\
\hline
\end{tabular}

Note: Population: 41,00,000 (12,22,745 in rent), silk production in 2017/018: 5t, data on jute, cotton, rubber: NA. 
Table 2. Agricultural strategy for sustainable availability of food fiber and flowers in valley 2019/20

\begin{tabular}{|c|c|c|c|c|c|c|c|}
\hline $\begin{array}{l}\mathbf{S} \\
\mathbf{N}\end{array}$ & $\begin{array}{l}\text { Commodity } \\
\text { (processed) }\end{array}$ & $\begin{array}{c}\text { Raising } \\
\text { productivity }\end{array}$ & $\begin{array}{l}\text { Area/heard } \\
\text { expansion }\end{array}$ & SN & $\begin{array}{l}\text { Commodity } \\
\text { (processed) }\end{array}$ & $\begin{array}{c}\text { Raising } \\
\text { productivity }\end{array}$ & $\begin{array}{c}\text { Area/heard } \\
\text { expansion }\end{array}$ \\
\hline 1 & Cereals & $0.19 \mathrm{t}$ & $3,17,563 \mathrm{ha}$ & 10 & Flowers & Rs 1.93 mil & 435ha \\
\hline 2 & Pulses & $0.33 \mathrm{t}$ & $1,22,670 \mathrm{ha}$ & 11 & Tea & $0.05 \mathrm{t}$ & 2,883 ha \\
\hline 3 & Vegetables & $1.28 \mathrm{t}$ & 50,536 ha & 12 & Coffee & $0.02 t$ & 813 ha \\
\hline 4 & Potato/tubers & $1.80 \mathrm{t}$ & 28,532 ha & 13 & Meat* & NA & *Nos \\
\hline 5 & Fruits & $0.93 \mathrm{t}$ & 11,132 ha & 14 & Fish & $4.51 \mathrm{t}$ & 9,209 ha \\
\hline 6 & Spices & $0.11 \mathrm{t}$ & 15,889 ha & 15 & Milk & $0.18 \mathrm{t}$ & $2,88,870 \mathrm{Nos}$ \\
\hline 7 & Sugar & $0.83 \mathrm{t}$ & 16,118 ha & 16 & Eggs & $25.11 \mathrm{pc}$ & 7,60,909Nos \\
\hline 8 & Oil seed & $0.31 \mathrm{t}$ & $1,78,053 \mathrm{ha}$ & 17 & Wool & $490 \mathrm{~g}$ & $5,88,670$ Nos \\
\hline 9 & Honey & $7 \mathrm{~kg}$ & $1,03,333$ hives & & & & \\
\hline
\end{tabular}

Note: Data on jute cotton silk and rubber is not available. $* 68,100$ buffalo; $2,79,500$ goats; 14,500 pigs and $17,00,000$ poultry birds.

\section{Availability and sufficiency of milled cereals}

Per capita cereals requirement in Kathmandu valley was estimated rice $89 \mathrm{~kg}$, maize 45 , wheat 45 , millet 10 , buckwheat 1 , and barley $1 \mathrm{~kg}$. Total per capita consumption of cereals in the year $2017 / 018$ was $191 \mathrm{~kg} /$ person/year. Thus, the annual cereals requirement in Kathmandu valley seemed 7,83,100t by consumption which in fact it is $7,50,300 t$ by ICMR [14] and WHO [15] recommendations. Production of cereals in the valley in the year 2017/018 was only $98,894 \mathrm{t}$ which was $2 \%$ of national production [16], though $14.4 \%$ of Nepal populations are living in the valley. Thus, it seems 6,84,204t/year cereals deficit by the consumption and 6,51,406t by [14] recommendations in Kathmandu valley. Moreover, the national production of cereals (milled) in the same year $(72,52,657 \mathrm{t}$ ) also was not self sufficient [16] with the deficit of 5,78,343t by actual consumption and 1,96,440t by ICMR [14] recommendation (Table 1). The future strategy for the cereals self sufficiency in Kathmandu valley as per the ICMR [14] recommendation needs either expansion of early rice and winter maize area or to raise the cereals productivity throughout the country. Expansion of $1,28,521$ ha spring rice area provision with drying and paddy procurement by Government in nation or increase the productivity by $0.2 \mathrm{t} / \mathrm{ha}$ through improved cultivation practices can sufficiently feed the people in Kathmandu valley (Table 2). Moreover it also needs to use hybrid rice and maize throughout the country. Immediate action to stop illegal export of paddy from Terai to India collection and storage about 3,42,103t/year paddy in season as the buffer stock in Kathmandu valley is needed. Emphasize should be given for the alternative staple foods like potato minor crops or ready foods to discourage the rice culture. It needs to increase the investment on agriculture covering area expansion raising cereals productivity infrastructure support on ware houses and provision of grain dryer and other necessary inputs.

\section{Availability and sufficiency of milled pulses}

Nepal grows lentil, black grams, grams and many other pulses in different geography [16]. Though, Kathmandu valley does not produce pulses however, the consumption in the year 2017/018 was 47,150t. In fact, the figure was quite less than the ICMR [14] and WHO [15] recommendations that comes 1,06,600t/year. Nepal was also seriously deficit in pulses in the same year (Table 1). The future strategy to supply pulses in Kathmandu valley can be expansion of pulses area or raise the productivity in the country side. It needs to expansion of pulses area by 1,22,669 ha to meet the valley demand. Alternatively increasing the productivity by $0.32 \mathrm{t} / \mathrm{ha}$ throughout the country also can meet the deficit but it is too hard to meet (Table 2). Valley need to maintain the buffer stock of pulses by $50 \%$ of its yearly need (53,300t/year). The alternative protein sources from fish and animal sources can minimize the pulses requirement. Moreover it needs to increase the investment on pulses production in Nepal that covers output based incentives to farmers for additional productivity. Long term and farm subsidy support on construction of ware houses pulses mills and other inputs can enhance the pulses sufficiency.

\section{Availability and sufficiency of kitchen supplied vegetables and spices}

People in Kathmandu valley consumed 3,11,600t kitchen supplied vegetables in the year 2017/018 [16]. The 
consumption was higher than the ICMR [14] and WHO [15] recommendations. In fact, the consumption shall be suffice by $2,99,300 t / y e a r$ as per the recommendation. The estimated local production of kitchen supplied vegetables in Kathmandu valley in the year $2017 / 018$ was about $2 \%$ of national production $(56,247 \mathrm{t})$. Thus, Kathmandu valley was deficit by $2,55,353 \mathrm{t} /$ year from consumption and $2,43,053 \mathrm{t}$ by ICMR [14] recommendations, annually. Similarly, valley consumption of spices like ginger garlic chilly etc. in the year 2017/018 was 12,300t. Kathmandu valley produced $1,336.34 \mathrm{t}$ (estimated $2 \%$ of national production). Thus, Kathmandu valley deficit $10,964 \mathrm{t}$ spices annually (Table 1 ). Expansion of cultivated area raising the productivity or the combination of both in and around valley and across the country can restore sustainable supply of vegetable and spices in the valley. That covers 50,536ha area expansion or raising productivity by $1.2 \mathrm{t} / \mathrm{ha}$ across the country. The sufficiency of species in Kathmandu valley needs $15,890 \mathrm{ha}$ area expansion or raising productivity by $0.12 \mathrm{t} / \mathrm{ha}$ on national base (Table 2). Establishment of high tech green houses provision of whole sale market with grading packaging and Rapid Pesticide Testing (RPT) facilities linked with national and international markets are necessary. Immediate action should be taken on collection and distribution facilities with cold chain and cold storages in Kathmandu valley and in its periphery. However it needs a big investment for output based incentives and technological backup.

\section{Availability and sufficiency of kitchen supplied tubers/potato}

A total of 4,10,000t kitchen supplied potato has been consumed in the year 2017/018 [16] in Kathmandu valley. The consumed quantity seems too high as per the ICMR [14] and WHO [15] recommendation (1,31,200t/year). Production of potato in the same year in the valley was only $50,500 \mathrm{t}$ which is about $2 \%$ of national production [16]. Therefore, Kathmandu valley deficit about $3,59,500 \mathrm{t}$ of table potato each year by consumption and only $80,700 \mathrm{t}$ by ICMR recommendation (Table 1). The expansion of potato/tubers area by $28,532 \mathrm{ha}$ in or around Kathmandu valley or raising productivity by $1.89 \mathrm{t} / \mathrm{ha}$ on national base can sustain the demand of potato in the valley (Table 2). Establishment of high tech hydroponic houses for Pre Basic Seed (PBS) production and tissue culture labs provision of sale markets linked with international markets with collection transportation grading packaging and RPT facilities with cold chain and capacious cold storages in Kathmandu valley and in its periphery are important. It needs to improve the public and private investment for area expansion raising productivity and supporting output based incentives on inputs and basic infrastructures.

\section{Availability and sufficiency of table fruits}

The consumption of table fruits in the year 2017/018 in Kathmandu valley was 69,700t [16]. The per capita consumption and the volume consumed were higher than the ICMR [14] and WHO [15] recommendations $(45,100 t / y e a r)$. The production of table fruits in Kathmandu valley in the same year was only 20,366.16t with the deficit of 49,334t on consumption and 24,734t/year as per ICMR [14] and WHO [15] recommendation. The deficit was dominantly apples, grapes, oranges, mango, pomegranate, lemon and nuts importing from aboard (Table 1). The future strategy for the sustainable supply of fruits in Kathmandu valley needs area expansion of sub tropical and sub temperate fruits by $11,132 \mathrm{ha}$ in or around Kathmandu valley or raising productivity of fruits by $2.0 \mathrm{t} / \mathrm{ha}$ in national base (Table 1 ). The synergy can be given from establishment of high tech green houses for fruit nurseries and high density fruit orchards in or around valley or outside the valley. Development of fruit central market provision with grading packaging and RPT facilities handle by cooperatives and linked with other national and international whole sale markets are most important. Immediate action to maintain cold chain and capacious cold storages in Kathmandu valley and in its periphery are equally important. For this, an increased public and private investment is needed.

\section{Availability and sufficiency of sugar}

The sugar consumption in Kathmandu valley in the year 2017/018 was 44,690t [16]. The per capita sugar consumption and the volume consumed in Kathmandu seem lower than ICMR [14] and WHO [15] recommendations that becomes 65,600t/year (Table 1). Sugar production in Kathmandu valley was nil so valley was deficit on sugar production by $100 \%$ and mainly dependent to imports. It needs expansion of sugarcane area by 16,118 ha or raising productivity by $0.83 \mathrm{t} / \mathrm{ha}$ on national base or the combination of the both to sustain the sugar supply in valley (Table 2). The program should be synergized with the maintenance of 50\% deficit sugar as the buffer stock in Kathmandu valley $(32,800 t /$ year). Improve relationship between cane farmers and mills with placing the immediate payment system increase custom duty up to $50 \%$ on sugar import and band on sugarcane import are equally beneficial for the domestic farmer's, millers and consumers. Moreover, it needs improved investment for sugarcane research variety development cane extension and output base supports on input supply and infrastructure development.

\section{Availability and sufficiency of edible oils and fats}


Consumption of edible oils and fat in Kathmandu valley in 2017/018 was 16,400t [16]. It seems the people in Kathmandu valley consume lower amount of edible oils and fats than ICMR [14] and WHO [15] recommendations that becomes 65,600t annually. Production of edible oils and fat in Kathmandu valley in the same year was only 1,501t [16]. Thus the deficit of edible oils and fat in the valley in this year was estimated 14,899t by consumption and by $34,099 \mathrm{t}$ by ICMR [14] and WHO [15] recommendations (Table 1). Future strategy to meet the sufficiency of oil and fats in Kathmandu valley covers raising productivity by $0.17 \mathrm{t} / \mathrm{ha}$ or increasing oilseed area by 94,719 ha on national base (Table 2). However, combination of the both seems best alternative. Maintenance of buffer stock of $50 \%$ deficit $(17,050 \mathrm{t})$ with improved regulation for quality control and preventing adulteration are needed. All these efforts need an improved investment.

\section{Availability and sufficiency of honey}

Consumption of table honey in the year 2017/018 in Kathmandu valley was 886.9t. There lacks the recommendation on honey consumption. However, the per capita consumption of table honey if assume to be $0.5 \mathrm{~kg} / \mathrm{person} / \mathrm{year}$ the annual requirement of Kathmandu valley becomes 2,050t/year. The production of table honey in the year 2017/018 in Kathmandu valley alone was estimated $14 \%$ of national production that is $500 t$ [16]. Thus, the estimated deficit of table honey in Kathmandu valley was 386.9t/year from actual consumption and 1,550t by estimated per capita recommendation (Table 1). It needs establishment of new apiaries with additional 1,03,333 hives or raising productivity by $7.0 \mathrm{~kg}$ honey/hive on national base or the combination of both can sustain the table honey supply in Kathmandu valley (Table 2). Establishment of collection processing packaging storage and transportation infra-structures product diversification and linking with national and international markets with the improved investment can assure honey supply in Kathmandu valley.

\section{Availability and sufficiency of cut flowers}

Annual import of the flowers in the year 2017/018 in Nepal was of NPR 10,18,00,000 and export of NPR 36,46,000 [16]. Seventy percent of total transaction in floriculture in Nepal was only in Kathmandu valley. Big demand was in Dipawali festival. The consumption/use of cut flowers in Kathmandu valley in the year 2017/018 was equal to NPR $20,00,00,000$. However, the assured availability and distribution can double its consumption. Floriculture in Nepal in the year 2017/018 was only in 153ha (Table 1). Future strategy to achieve cut flower sufficiency in Kathmandu valley needs expansion of floriculture area by 435.46ha in or around the valley (Table 2). In addition, establishment of high tech green houses in valley and around the valley together with whole sale markets linked with national and international markets with grading-packaging facilities and provision of cold chain/capacious cold storages in Kathmandu valley and in its periphery or in production sites are needed. It also needs improved public and private investment.

\section{Availability and sufficiency of tea and coffee}

National Tea and Coffee Board reported that the consumption of fine tea in Kathmandu valley in the year 2017/018 was 1,845 t. Kathmandu valley does not produce the tea. So all the tea consumed was imported from outside the valley. Moreover, the consumption of coffee in the year 2017/018 in Kathmandu valley alone was 70t. Lalitpur produced 5t table coffee in the same year [17]. So Kathmandu valley was deficit by $65 t$ table coffee annually (Table 1). The future strategy to sustain the tea and coffee supply in Kathmandu valley it needs to emphasize on tea and coffee plantation and orchard management in production sites, establishment of coffee processing plant, strengthen the distribution system and maintain quality standards. It needs the investment on production inputs infrastructure support on processing packaging and marketing.

\section{Availability and sufficiency of meat}

The meat consumption in Nepal includes buff $65 \%$, mutton $20 \%$, pork $7 \%$, and poultry $8 \%$. Kathmandu valley consumed about $15 \%$ of total meat consumption in Nepal. A total of $49,200 \mathrm{t}$ meat was consumed in valley in the year 2017/018. The consumption was at par the ICMR [14] and WHO [15] recommendation (45,100t/year). The estimated volume of meat production in valley was about $2 \%$ of national production $(7,287 \mathrm{t})$. Thus, the meat deficit in valley was $41,913 \mathrm{t}$ by actual consumption and 37,813t/year by ICMR [14] recommendation (Table 1). The meat demand in Kathmandu valley was increasing by $12 \%$ annually. The future strategy for meat sufficiency in Kathmandu valley covers establishment of new 681 buffalo fattening farms (100 heads/farm), 559 goat farms (500 heads/farm), 29 piggery (500 heads/farm) and 34 poultry farms (50,000 birds/farm) in and around Kathmandu valley. For this, the private and public investment shall be increased. 


\section{Availability and sufficiency of fish from pound and river}

The total consumption of fishes in Kathmandu valley in 2017/018 was 28,700t. Production of fishes in valley in $2017 / 018$ was $250 t$ only [16]. Thus, valley deficit annually on fish by $28,450 t$ by consumption and $44,850 t / y e a r$ by recommendations (Table 1). The growth rate of fishery sector was $14 \%$ in Nepal and the fish demand was increasing by $15 \%$ annually. The protein malnutrition in the country including in Kathmandu valley can be solved from fishery and is the cheep source of protein than the pulses and other animal sources. The future strategy to have sustained supply of fish in Kathmandu valley covers establishment of new fish farms in 9,209ha or increasing productivity or the combination of both (Table 2). Moreover maintaining scientific/judicious catch from the rivers and natural ponds was also equally important. Establishment of hatchery and feed industries can give the synergy. These efforts demand an output based significant investment especially on establishment of new fish ponds production inputs feed industries hatcheries other infrastructure development including cold chain and fish marketing.

\section{Availability and sufficiency of milk (buffalo and cattle)}

Milk consumption in the year 2017/018 in Kathmandu valley was 2,95,200t [16] which was slightly higher than ICMR ${ }^{[14]}$ recommendation $(2,25,500 t /$ year $)$. Milk production in valley in the same year was $40,900 t$ [16]. Thus, the annual milk deficit in Kathmandu valley by consumption was 2,54,300t and $1,84,600$ t by ICMR (1985) recommendations (Table 1). Moreover, the annual milk demand in Nepal was increasing by $8 \%$ and the rate was slightly higher in Kathmandu valley. Future strategy for the sustained milk supply in Kathmandu valley covers establishment of 2,889 new dairy buffalo/cow farms with at least 100 dairy animals in or around valley or to increase the national milk productivity by $0.18 \mathrm{t} / \mathrm{year} / \mathrm{cow}$ or buffalo $(18,11,320$ milking heads) (Table 2$)$. This should be supported by improved milk collection processing/packaging and distribution/marketing systems throughout the country. All these need a significant public and private investment.

\section{Availability and sufficiency of poultry eggs (chicken and ducks)}

Total consumption of poultry eggs (chicken and ducks) in Kathmandu valley was estimated 20,91,00,000 pieces in $2017 / 018$ [16]. The consumption of eggs in Kathmandu valley was slightly higher than the ICMR [14] recommendations $(19,68,00,000$ pieces/year). The estimated production of eggs in valley in the same year was $2,94,00,000$ pieces which was $3 \%$ of national production [16]. Thus, valley was deficit on poultry eggs by 17,97,00,000 pieces annually by consumption and 16,74,00,000 pieces by ICMR [14] recommendation (Table 1). The demand of poultry eggs was increasing by $8 \%$ annually. Future strategy for the sustained supply needs establishment of 15 new poultry farms that holds more than 50,000 birds each in or around Kathmandu valley. Increasing the productivity by 25 eggs/bird/year at national base can also meet the demand (Table 2). The program should back up from different production inputs vet services and infrastructures support that covers poultry shades hatcheries feed industry collection storage and distribution system. All these need improved investment.

\section{Availability and sufficiency of wool}

Total consumption/use of wool by the wool industries in Kathmandu valley in the year 2017/018 was 412 t. It was about $70 \%$ of the national consumption/demand. Valley does not produce any wool and all the wool used in valley is imported from outside the valley and aboard (Table 1). Establishment of 1,177 new sheep farms that holds more than 500 sheep each can meet the sufficiency of Kathmandu valley alone. Alternatively raising productivity by $490 \mathrm{~g}$ wool/sheep/annum at national level or the combination of the both can serve the purpose (Table 2). For the sustained wool supply in Kathmandu valley it needs a good investment for establishing the new sheep farms increasing the herd sizes sheep breeding for better wool production and infrastructure support.

\section{Availability and sufficiency of fibers (cotton jute $\&$ silk) and rubber}

Different industries and the people are using a big volume of fibers like cotton jute and silk in Kathmandu valley. Some of the manufacturing industries also used a considerable volume of natural rubber. The demands of these materials are rapidly increasing. They are not producing in valley (Table 1). So valley totally depends on import of these commodities. Strengthening the production program outside the valley needs to substitute the national import.

\section{SSR and IDR of foods fibers rubber and flowers in Kathmandu valley}

Kathmandu valley was not self sufficient on any of the primary agricultural products (Table 3 ).

The Import Dependency Ratio (IDR) of pulses, sugar, silk, jute, rubber, cotton, tea, and wool was $100 \%$ in the year 2017/018. Similarly the commodities having high IDR were fishes $99.1 \%$, oils and ghee $90.8 \%$, coffee $92.9 \%$, spices 
$89.1 \%$, milk $86.1 \%$, potato $87.7 \%$, meat $85.2 \%$, cereals $87.4 \%$, vegetables $81.9 \%$, eggs $85.9 \%$, fruits $70.8 \%$, honey $43.6 \%$ and cut flowers $74.0 \%$ (Table 3 ).

Table 3. Yearly IDR and SSR of milled/dressed foods fibers and flowers in Kathmandu valley 2017/018

\begin{tabular}{ccccccc}
\hline SN & Commodity & Production & Deficit & Consumption & SSR (\%) & IDR (\%) \\
\hline 1 & Cereals & $98,894 \mathrm{t}$ & $6,84,206 \mathrm{t}$ & $7,83,100 \mathrm{t}$ & 12.6 & 87.4 \\
2 & Vegetables & $56,247 \mathrm{t}$ & $2,55,353 \mathrm{t}$ & $3,11,600 \mathrm{t}$ & 18.1 & 81.9 \\
3 & Potato/tubers & $50,500 \mathrm{t}$ & $3,59,500 \mathrm{t}$ & $4,10,000 \mathrm{t}$ & 12.3 & 87.7 \\
4 & Fruits & $20,366 \mathrm{t}$ & $49,334 \mathrm{t}$ & $69,700 \mathrm{t}$ & 29.2 & 70.8 \\
5 & Spices & $1,336 \mathrm{t}$ & $10,964 \mathrm{t}$ & $12,300 \mathrm{t}$ & 10.9 & 89.1 \\
6 & Oil/Ghee & $1,501 \mathrm{t}$ & $14,899 \mathrm{t}$ & $16,400 \mathrm{t}$ & 9.2 & 90.8 \\
7 & Honey & $500 \mathrm{t}$ & $386.9 \mathrm{t}$ & $886.9 \mathrm{t}$ & 56.4 & 43.6 \\
8 & Flowers (Rs) & Rs $104 \mathrm{mil}$ & Rs 296mil & Rs 400mil & 26.0 & 74.0 \\
9 & Coffee & $5 \mathrm{t}$ & $65 \mathrm{t}$ & $70 \mathrm{t}$ & 7.1 & 92.9 \\
10 & Meat & $7,287 \mathrm{t}$ & $41,913 \mathrm{t}$ & $49,200 \mathrm{t}$ & 14.8 & 85.2 \\
11 & Fish & $250 \mathrm{t}$ & $28,450 \mathrm{t}$ & $28,700 \mathrm{t}$ & 0.9 & 99.1 \\
12 & Milk & $40,900 \mathrm{t}$ & $2,54,300 \mathrm{t}$ & $2,95,200 \mathrm{t}$ & 13.9 & 86.1 \\
13 & Eggs (000) & $2,94,00 \mathrm{pc}$ & $17,97,00 \mathrm{pc}$ & $20,91,00 \mathrm{pc}$ & 14.1 & 85.9 \\
\hline
\end{tabular}

Note: IDR of pulses sugar tea jute rubber cotton wool and silk was $100 \%$.

\section{Discussions}

Kathmandu valley was not independent to any of the primary agriculture products on its own production. However, there was a scope to reducing the IDR of agriculture commodities through enhancing the urban agriculture. It covers better utilization of available land, vertical farming, roof top farming, hydroponics, aquaponics, home gardening and kitchen gardening. Reference [6] reported that over 800 million people worldwide are practicing urban agriculture. Around 34\% of Sydney's total food supply or the entire vegetable supply is through urban agriculture [8]. Over 200 smart cities including New York have declared making their food system more sustainable, equitable, resilient and healthy following the "Milan Urban Food Policy Summit 2015". Furthermore, Milan is pioneering the open innovation hub for urban farming [18].

There are lands available in peri urban areas feasible to intensive cultivation of vegetables, cereals, livestock and beekeeping, to supply the product in Kathmandu valley. However, valley needs to finance these peri-urban and rural communities for the establishment of new commercial agricultural and livestock farms or to expand the existing farm sizes by increasing the number of animal heads or cultivated areas to produce more and more foods fibers and flowers supplying in the valley. However, expanding the farm sizes is not possible for every commodity. Countries like the US China and Brazil either have larger land masses or they are part of bigger economic unions have scope for the expansion of the cultivated areas and herd/farm sizes for the commercial production [19]. In Japan, municipalities prepare the land-use plans in accordance with national and prefectural laws and regulations and pass auxiliary regulations guiding land use and food production in their jurisdictions [20]. In USA, the change on land use and food production is made on the basis of commodity prices market forces production technology government policies and the returns from it [21]. Kathmandu valley and Nepal lacks such provisions. Where, the available land is limited and area expansion of a commodity is not possible without reducing the area of another. Thus, it needs to prioritize the commodities to allocate the cultivated land areas for crop farming, fish ponds, apiary or the livestock farm or pasture. Moreover, establishment of large size, high tech farms like buffalo fattening farms, goat farms, piggery, poultry farms, apiary, fish farms, high density fruit orchards and commercial organic vegetable farms in rural community are necessary to feed the even growing city population and achieve national food sufficiency. It can also generate rural employment and income for the economic resilience.

In addition, an increased productivity increases the farm incomes and fueling the linkages between farm and non-farm poverty reduction programs which are the consequences of agricultural growth [22]. The average cereal productivity in the world is $4.0 \mathrm{t} / \mathrm{ha}$ [23] vegetables $13.9 \mathrm{t} / \mathrm{ha}$ and fruits $12.04 \mathrm{t} / \mathrm{ha}$ [24]. The crop and animal productivity in several other countries are very high. The productivity of corn alone in USA is $10.07 \mathrm{t} / \mathrm{ha}$ [25]. Where, the vegetables 
yield was 31.3t/ha [26] and the cereals yield 5.5t/ha [27] in Denmark in the year 2018. In addition, the average dairy farm has 160 cows and the average milk yield per cow was 10,300kg/yr in Denmark in the year 2015 [28]. The food productivity is comparatively very low in Nepal [16]. Nepal is classified as severe localized food insecure country with increasing import dependency ratio in each year. Nepal is self sufficient only on tea, coffee, and poultry eggs. Where, the self sufficiency ratios (SSR) of cereals $(97.4 \%)$, vegetables $(65.9 \%)$, potato $(88.8 \%)$, milk $(79 \%)$, sugar $(62.6 \%)$ and meat $(61 \%)$ are still higher. However, the import dependency ratio of fruits $(88.1 \%)$, oils $(83.5 \%)$ and pulses $(73.4 \%)$ are very high and are in increasing trend [29]. In this connection, Kathmandu valley should invest for improved farming in its peri-urban areas and the rural communities for raising the food, fiber and flower productivity that can support the sustainable supply of in the city. But the food productivity can only increase only to a limit with a strong research and technical back up, technology, infrastructure funding support and an enabling environment [29].

The schedule of food production, collection and distribution has been affected leading to hassling, product wastage and price fluctuations by the impact of Covid-19 lockdown in 2020. Resumption of full-fledged farming operations and revival of agri-based enterprises is needed for the livelihood recovery and economic resilience in post lockdown period. It is needed to reform the policy on land use, food security and priority settings on establishing new commercial agriculture farms, expansion of crop area/heard sizes and making agriculture the most attractive business in Nepal [30]. It can support for sustainable food supply in Kathmandu valley too. In the other hand, urban agriculture, roof top farming, vertical farming and kitchen gardening also can support local food supply in valley.

Consumption of potato, cereals and some other food seemed higher than ICMR [14] and WHO [15] recommendation in Kathmandu valley. Therefore, food education is needed to improve the food and nutrition consumption, balancing diet and minimize food waste in the cities of Nepal [31]. India has its own per capita diet/food recommendation [14]. However, Nepal lacks such food/diet recommendation.

\section{Conclusion and recommendations}

People in Kathmandu valley are most insecure on food fibers and flowers. The IDR of pulses sugar silk jute rubber cotton tea and wool were $100 \%$. Where, the IDR of fish was $99.1 \%$, oils and ghee $90.8 \%$, coffee $92.9 \%$, spices $89.1 \%$, milk $86.1 \%$, potato $87.7 \%$, meat $85.2 \%$, cereals $87.4 \%$, vegetables $81.9 \%$, eggs $85.9 \%$, fruits $70.8 \%$, honey $43.6 \%$ and cut flowers $74.0 \%$. Kathmandu valley cannot be self sufficiency on all these commodities. However, the IDR can be reduced through better recycling the city waste and the adoption of the urban agriculture with high tech vertical farming and best utilization of the available land and spaces. It can make the valley self sufficient at least on vegetables, potato, spices and honey. However, establishment of new agriculture farms, expansion of cropping area and livestock herd sizes or the combination with intensive and improved farming practices for increasing the productivity, in/around valley and across the country is needed to restore the valley food/fiber/flower security. It needs to invest the rural agriculture by the urban economy.

Based on the study following recommendations are made:

- Best utilization of available land and the city spaces as urban agriculture and vertical farming for strengthening the local food supply system.

- Establishment of high tech green houses, high tech nurseries, high tech high density large fruit orchards, large farms, hydroponic houses and tissue culture labs are recommended. Establishment of new buffalo fattening farms, goat farms, piggery, poultry farms, apiary and fish farms are needed.

- The programs on variety/breed improvement, fodder and feed management, infrastructure support, veterinary services, hatcheries, use of high yielding varieties/breeds and management of production inputs for raising the productivity across the country are needed.

- Immediate action to stop illegal export of paddy and other cereals from Terai boarder and divert to cities needed. Maintenance of buffer stocks of non perishable at least $50 \%$ of valley requirement is recommended. Establishment of capacious cold storage, maintain the cold chains, collection centers and whole sale market linked with national and international markets and e-auction centers are recommended for the perishables.

- Minimum support programs for the self sufficiency of rubber, jute, cotton and silk are also necessary.

- It is recommended to have strong food education to reducing per capita cereal consumption, reducing city food waste and discourage rice culture in Kathmandu valley.

- It needs to increase output based integrated investment on urban and rural agriculture. Special focus on supporting rural agriculture through urban economy is recommended.

\section{References}

[1] FAO (Food and Agriculture Organization). (2003). The state of food insecurity in the world. Retrieved 07 March 2019 from http://www.fao.org/docrep/006/j0083e/j0083e00.htm.

[2] Global Food Security Index. (2016). Annual measure of the state of global food security. Retrieved 07 March 2019 from 
https://www.google.com/search?ei=P9hTXZjzGcao9QO2tIvoDg\&q=global+food + security + index $+2016 \&$ oq $=$ global + food + sec urity+index+2016\&gs_l=psyab.1.0.0i19j0i22i30i19.1304612.1304612..1311200...0.0..0.199.199.0j1.....0....1..gws-wiz.jfS9W YAGj0s.

[3] Global Hunger Index. (2018). Retrieved 07 March 2019 from https://www.acted.org/en/global-hunger-index-2018/.

[4] WFP (World Food Program). (2015). Hunger map 2015. Retrieved 07 March 2019 from https://www.acww.org.uk /assets/wfp2750571.pdf.

[5] Chitrakar, A. (2010). My tribute to a book about food. The life of food in Nepal. WFP publication. P7.

[6] FAO (Food and Agriculture Organization). (2020). Five ways to make cities healthier and more sustainable. Retrieved 20 May 2020 from http://www.fao.org/fao-stories/article/en/c/1260457/.

[7] Meredith, G. (2015). The Death of Distance: Food Deserts Across the Global Divide. Retrieved 20 May 2020 from https://www.researchgate.net/publication/304802977_The_Death_of_Distance_Food_Deserts_Across_the_Global_Divide.

[8] Robert, M., Rader, R., and Kristiansen, P. E. (2020). Urban agriculture could provide 15\% of food supply to Sydney Australia under expanded land use scenarios. Retrieved 20 May 2020 from https://www.researchgate.net/publication/339674839 _Urban_agriculture_could_provide_15_of_food_supply_to_Sydney_Australia_under_expanded_land_use_scenarios.

[9] Shakya, S. (2010). From farm to market. The life of food in Nepal. WFP publication. P. 18

[10] e-Krishi Shiksha. (2020). Crop process engineering. Retrieved August 10, 2020 from: http://www.ddgs.umn.edu/articlesproc-storage-quality/2001-Davis-\%20Processing.pdf.

[11] Devkota, A. R., Dhakal, D. D., Gautam, D. M., and Dutta, J. P. (2014). Assessment of fruit and vegetable losses at major wholesale markets in Nepal. Int J Appl Sci Biotechnol., 2(4), 559-562.

[12] Chourasia, M. K., Maji, P., Baskey, A., and Goswami, T. K. (2005). Estimation of moisture loss from cooling data of potatoes. Journal of Food Process Engineering, 28(4), 397-416.

[13] Christopher, R. R. (1999). The butcher kept your meat? Retrieved 12 August 2020 from: https://animalscience.psu.edu /extension/meat/pdf/The\%20Butcher\%20Stole\%20My\%20Meat.pdf.

[14] ICMR (Indian Council of Medical Research). (1985). Nutritional requirements in India. Retrieved 07 March 2019 from http://www.fao.org/3/x0172e/x0172e02.htm.

[15] WHO (World Health Organization). (1986). In Max Roser and Hannah Ritchie 2018. Food per person. Retrieved 07 March 2019 from https://ourworldindata.org/food-per-person.

[16] MoAD (Ministry of Agriculture Development). (2017/018). Statistical information on Nepalese agriculture $2017 / 018$. Agri-Business Promotion and Statistics Division Singha Durbar Kathmandu Nepal.

[17] TCDB (Tea and Coffee Development Board). (2017/018). Annual Report, 2017/018.

[18] Smart city. (2019). How can smart cities have self-sufficient food system? Pioneers are here to inspire! Retrieved 20 May 2020 from https://www.smartcity.press/food-system-in-smart-cities/.

[19] Sushma, M. (2018). Hunger amid abundance: The Indian food security enigma. Retrieved 27 April 2020 from www.futuredirections.org.au > ...

[20] OECD (Organization for Economic Co-operation and Development). (2017). The governance of land use. Retrieved 29 April $2020 \mathrm{from} \mathrm{https://www.oecd.org/regional/regional-policy/land-use-Japan.pdf.}$

[21] Nickerson, C. and Borchers, A. (2012). How is land in the United States used? A focus on agricultural land. Retrieved 29 April 2020 from https:/www.ers.usda.gov/amber-waves/2012/march/data-feature-how-is-land-used/.

[22] Dhital, P. R. (2017). Agricultural extension in Nepal: experiences and issue. Retrieved 12 February 2020 from https://www.researchgate.net/publication/319617467_.

[23] The World Bank Group. (2019). Cereal production. Retrieved 29 April 2020 from https://data.worldbank.org/indicator /AG.PRD.CREL.MT.

[24] FAO (Food and Agriculture Organization). (2010). Statistical yearbook of the Food and Agricultural Organization. Retrieved 30 April 2020 from www.fao.org/3/i3138e/i3138e05.pdf.

[25] Wikipedia. (2020). Agriculture in the United States. Retrieved 29 April 2020 from https://en.wikipedia.org /wiki/Agriculture_in_the_United_States\#Yield.

[26] Knoema. (2018). Denmark primary vegetables yield. Retrieved 30 April 2020 from https://knoema.com/atlas/Denmark/topics /Agriculture/Crops-Production-Yield/Primary-vegetables-yield.

[27] Martin, L. (2018). Statistics Denmark. Retrieved 30 April 2020 from https://www. dst.dk/en/Statistik/emner /erhvervslivets-sektorer/landbrug-gartneri-og-skovbrug/vegetabilsk-produktion.

[28] Henrik, N. (2015) Farming and milk production in Denmark. Retrieved 30 April 2020 from https://www.whff.info /documentation/documents/ehc2007/02\%20Farming\%20and\%20milk\%20production\%20in\%20Denmark.pdf).

[29] Pokhrel, S. (2020). Food availability and consumption in relation to developing strategies for sustained production and supply in Nepal. Journal of Agriculture and Forestry University, 4: 13-28. 
[30] Pokhrel, S. (2020). Impact of Covid-19 Lockdown on Agriculture and Developing Strategies Against it for Sustained Food Production and Supply: Special Focus to Nepal. Journal of Environment Sciences (JoEnvSc)., 6: 1-11.

[31] NeKSAP (Nepal Food Security Monitoring System). (2011/012). Nepal Food Balance by Districts. Retrieved 07 March 2019 from Nepal+Food+Balance+by+Districts+2011\%2F012\&oq=Nepal+Food+Balance+by+Districts+2011\%2F012 \&gs_l=psyab. 12...5565.10585..12705...0.0..0.381.1082.0j4j0j1..... 0....1j2..gws -wiz.Aihtq5XQ3v4. 